\title{
Pengaruh Model Contextual Teaching and Learning Berbantuan Masalah Realistis Terhadap Keterampilan Berpikir Kritis IPA
}

\author{
Ni Luh Putu Aninditha Paramita.A ${ }^{1}$, I Gusti Ngurah Japa ${ }^{2}$, I Gde Wawan Sudatha ${ }^{3}$ \\ ${ }^{12}$ Jurusan Pendidikan Dasar, ${ }^{3} J u r u s a n$ Teknologi Pendidikan \\ Universitas Pendidikan Ganesha \\ Singaraja, Indonesia \\ e-mail: \{paramita ${ }^{1}$, igustingurah.japa ${ }^{2}$, igdewawans $\left.{ }^{3}\right\} @ u n d i k s h a . a c . i d$,
}

\begin{abstract}
Abstrak
Penelitian ini dilakukan berdasarkan masalah pembelajaran yang pasif. Penelitian ini bertujuan untuk mengetahui pengaruh model Contextual Teaching and Learning berbantuan masalah realistis terhadap keterampilan berpikir kritis IPA siswa kelas IV Gugus II Teuku Umar Denpasar Barat Tahun Pelajaran 2018/2019. Jenis penelitian ini merupakan eksperimen semu dengan rancangan penelitian Non Equivalent Post-test Only Control Group Design. Populasi dari penelitian ini adalah seluruh siswa kelas IV SD Gugus II Teuku Umar Denpasar Barat dengan jumlah 240 siswa. Penentuan sampel dalam penelitian ini menggunakan teknik random sampling. Sampel dalam penelitian ini adalah siswab kelas IV SDN 13 Dauh Puri dengan jumlah 42 siswa sebagai kelompok eksperimen dan siswa kelas IV SDN 14 Dauh Puri dengan jumlah 40 siswa sebagai kelompok kontrol. Data keterampilan berpikir kritis IPA dikumpulkan dengan instrumen berupa tes essay berjumlah 10 soal yang telah divalidasi. Data yang diperoleh dianalisis dengan menggunakan metode statistik deskriptif dan statistik inferensial kemudian uji hipotesis menggunakan uji $t$. Berdasarkan hasil analisis data diperoleh $t_{\text {hitung }}=6,144$ lebih besar dari $t_{\text {tabel }}$ (pada taraf signifikan 5\%) = 1,988. Dilihat dari hasil perhitungan rata-rata berpikir kritis kelompok eksperimen adalah 87,245 lebih besar dari hasil rata-rata berpikir kritis kelompok kontrol yaitu 78,4. Dengan demikian berdasarkan hasil analisis data tersebut disimpulkan model CTL berbantuan masalah realistis berpengaruh terhadap keterampilan berpikir kritis IPA siswa kelas IV Gugus II Teuku Umar Denpasar Barat Tahun Pelajaran 2018/2019.
\end{abstract}

Kata Kunci : Contextual Teaching and Learning, IPA, keterampilan berpikir kritis, masalah realistis

\begin{abstract}
This research was conducted based on passive learning problem. This study aims to determine the effect of the Contextual Teaching and learning model assisted by realistic problems towards critical thinking skills in natural science fourth grade students of Group II Teuku Umar West Denpasar Academic Year 2018/2019. This type of research is a quasyi experiment using Non Equivalent Post-test Only Control Group Design. The population of this study were all fourth grade students of Elementary School Group II Teuku Umar West Denpasar with 240 students. Samples in this study were obtained using random sampling techniques. The sample in this study was fourth grade students of SDN 13 Dauh Puri with total of 42 students as an experimental group and fourth grade students at SDN 14 Dauh Puri with 40 students as a control group. Data on critical thinking skills of natural science are collected by essay tests totaling 10 questions that have been validated. The data obtained were analyzed using descriptive statistical methods and inferential statistics then tested the hypothesis using the $t$ test. Based on the results of data analysis obtained t count $=6.144$ greater than $t$ table (at a significant level of $5 \%)=1.988$. Based on the results of the calculation of the critical thinking average of the experimental group is 87.245 greater than the results of the critical thinking average of the control group, which is 78.4. Thus it was concluded that the CTL model assisted with realistic problems had an effect on the critical thinking skills of natural science students in fourth grade students of Group II Teuku Umar West Denpasar Academic Year 2018/2019.
\end{abstract}

Keywords: Contextual Teaching and Learning, natural science, critical thinking skills, realistic problem 


\section{Pendahuluan}

Perkembangan teknologi dan komunikasi di era globalisasi mengakibatkan perubahan diberbagai bidang. Indonesia sebagai bagian dari komunitas dunia harus dapat bersaing dan menyesuaikan diri dengan perubahan yang ada, sehingga dibutuhkannya sumber daya manusia yang berkualitas. Salah satu wahana untuk membentuk dan mengembangkan sumber daya manusia yang berkualitas adalah adanya pendidikan yang bermutu. Oleh karena itu, dalam penyelenggaraan pendidikan perlu adanya kerjasama yang baik dari berbagai pihak yang terkait seperti pemerintah dan guru.

Adapun upaya yang telah dilakukan untuk meningkatkan mutu pendidikan Indonesia, antara lain: (a) melakukan penyempurnaan kurikulum dari kurikulum berbasis kompetensi (kbk) menjadi kurikulum tingkat satuan pendidikan (ktsp) dan disempurnakan kembali menjadi kurikulum 2013, (b) peningkatan kompetensi guru melalui sertifikasi, (c) pengadaan dan perbaikan sarana dan prasarana sekolah. Pendidikan mempunyai peranan yang sangat penting untuk dapat menciptakan insan manusia yang cerdas, kompetitif serta kreatif, oleh karena itu pembaharuan dalam dunia pendidikan perlu dilakukan untuk mewujudkan pendidikan yang berkualitas. Pembelajaran harus menumbuhkan suasana sedemikian rupa sehingga siswa aktif bertanya, mempertanyakan, dan mengemukakan gagasan, dengan adanya perubahan ini, tentunya berbagai standar dalam komponen pendidikan juga akan berubah, baik standar isi, standar proses maupun standar kompetensi lulusan.

Ada sejumlah mata pelajaran di tingkat SD, IPA merupakan salah satu mata pelajaran pokok dalam kurikulum di Indonesia termasuk pada jenjang sekolah dan merupakan salah satu cabang ilmu pengetahuan yang memegang peranan penting dalam perkembangan ilmu pengetahuan. Menurut Suja (2014: 2) pembelajaran IPA diharapkan berdasarkan prinsipprinsip, proses, dan memberikan kesempatan penuh kepada peserta didik agar mampu berpikir dan bersikap terhadap alam melalui kegiatan pengamatan, diskusi, dan penyelidikan sederhana sehingga demikian peserta didik akan mendapatkan pengalaman belajar. Pengalaman belajar yang lebih bermakna dan menarik diharapkan dapat membantu peserta didik memahami dan mengingat pengetahuan yang didapat dalam waktu yang lama. Sehingga mutu pendidikan masih dianggap rendah karena kurang memberikan pengalaman belajar.

Namun pada kenyataannya sulit untuk direalisasikan, rendahnya mutu pendidikan salah satunya disebabkan oleh metode atau strategi yang digunakan oleh guru saat mengajar. Wina (2008) dalam proses pembelajaran, anak kurang didorong untuk mengembangkan kemampuan berpikir. Karena sebaik apapun kurikulum pendidikan apabila tidak diimbangi oleh pengimplementasian yang maksimal dan tepat guna maka hasil pendidikan yang diharapkan tidak akan tercapai maksimal. Dalam kurikulum 2013 siswa dituntut melalui beberapa proses secara aktif mencari, mengolah, mengkonstruksi, dan menerapkan pengetahuan. Maka sangat diperlukan upaya inovasi guru dalam mensiasati pembelajaran di kelas. Kenyataannya di lapangan masih banyak guru yang hanya berpaku yang hanya memberikan penugasan dalam membelajarkan siswa, sehingga pembelajaran terkesan masih didominasi guru. Ini menunjukkan adanya kesenjangan antara kenyataan di lapangan dan harapan sesuai kurikulum 2013.

Berdasarkan observasi pada hari Senin, 21 Januari 2018 pada siswa kelas IV Gugus II Teuku Umar Denpasar Barat suasana di kelas begitu pasif, sehingga siswa merasa bosan dalam mengikuti pembelajaran. Hal itu disebabkan karena pembelajaran IPA dianggap sebagai pelajaran sulit dan menjadi beban bagi siswa, selain itu guru masih menerapkan pembelajaran hanya berdasarkan pada buku pegangan saja, hal ini menyebabkan siswa kurang tertarik terhadap pelajaran. Hal itu, membuat pembelajaran lebih menekankan pada siswa untuk mengingat, menghafal, dan media pembelajaran hanya pada sumber-sumber di buku sehingga tidak menekankan pada siswa untuk pemecahan masalah dan mengaplikasikan pengetahuannya. Proses pembelajaran hanya diarahkan untuk menghafal informasi ke dalam otak tanpa dituntut untuk memahami informasi tersebut, sehingga model pembelajaran ini disebutkan dengan model pembelajaran langsung. Secara tidak langsung pola pembelajaran seperti itu akan membuat keterampilan berpikir siswa menjadi tidak optimal. hal inilah yang terjadi di SD Gugus II Teuku Umar Denpasar Barat Tahun Pelajaran 2018/2019.

Jika ini dibiarkan secara terus menerus maka akan berdampak kurang baik bagi siswa yaitu siswa menjadi kurang terlatih dalam bertanya, memberikan pendapat, memecahkan masalah dan menarik kesimpulan. Salah satu kecakapan hidup (life skill) yang perlu dikembangkan melalui proses pendidikan adalah keterampilan berpikir. Keterampilan berpikir sangatlah penting, karena kemampuan seseorang untuk dapat berhasil dalam kehidupannya 
antara lain ditentukan oleh keterampilan berpikir, terutama dalam upaya memecahkan masalahmasalah kehidupan yang dihadapinya. Berpikir kritis penting untuk dikembangkan terutama dalam mata pelajaran IPA karena pembelajaran akan lebih ekonomis, cenderung menambah semangat belajar dan membantu siswa memecahkan masalah. Oleh karena itu, berbagai upaya untuk meningkatkan mutu pendidikan harus selalu dilakukan baik dari kualitas guru, pendekatan pembelajaran maupun sarana dan prasarana.

Berdasarkan hasil pencatatan dokumen, memperlihatkan rata-rata nilai Ulangan Semester (UAS) Ganjil mata pelajaran IPA siswa kelas IV di Gugus II Teuku Umar Denpasar Barat tahun pelajaran 2018/2019 pada tabel 1.

Tabel 1.Data Nilai Rata-rata Ulangan Semester IPA Siswa Kelas IV

\begin{tabular}{ccccc}
\hline No & Nama Sekolah & $\begin{array}{c}\text { Jumlah } \\
\text { Siswa }\end{array}$ & $\begin{array}{c}\text { Kriteria Ketuntasan } \\
\text { Minimal (KKM) }\end{array}$ & $\begin{array}{c}\text { Nilai Rata-rata } \\
\text { IPA Kelas IV }\end{array}$ \\
\hline 1 & SD Negeri 2 Dauh Puri & 29 & 75 & 77.9 \\
2 & SD Negeri 10 Dauh Puri & 55 & 70 & 77.7 \\
3 & SD Negeri 12 Dauh Puri & 35 & 70 & 71.7 \\
4 & SD Negeri 13 Dauh Puri & 47 & 75 & 83.6 \\
5 & SD Negeri 14 Dauh Puri & 40 & 69 & 66.8 \\
6 & SD Negeri 21 Dauh Puri & 34 & 70 & 79.6 \\
& Nilai rata-rata kelas IV SD Gugus II Teuku Umar & 76.2 \\
\hline
\end{tabular}

(Sumber: Guru Mata Pelajaran IPA Kelas IV di Gugus II Teuku Umar Denpasar Barat).

Berdasarkan data tabel 1 dapat dikatakan bahwa rata-rata nilai IPA siswa kela IV Gugus II Teuku Umar Denpasar Barat tahun pelajaran 2018/2019 masih tergolong rendah. Cara mengatasi masalah yang ada pada siswa terhadap mata pelajaran IPA yaitu dengan melakukan pembenahan baik dari tenaga pendidik maupun peserta didik itu sendiri, pembenahan metode, strategi, atau model pembelajaran dalam pembelajaran IPA yang memungkinkan siswa untuk mengembangkan keterampilan berpikir kritisnya. Salah satu cara yang ditempuh yaitu dengan menerapkan model pembelajaran kontekstual (Contextual Teaching and Learning). Model CTL merupakan salah satu model dalam pembelajaran IPA yang dapat menumbuh kembangkan ketertarikan siswa pada mata pelajaran ini. Pembelajaran kontekstual merupakan konsep belajar yang membantu guru mengaitkan antara materi yang diajarkan dengan situasi dunia nyata siswa dan mendorong siswa membuat hubungan antara pengetahuan yang dimilikinya dengan penerapannya dalam kehidupan mereka sebagai anggota masyarakat (Supriyanto, 2007: 16). Dengan demikian Contextual Teaching and Learning (CTL) menjadikan pembelajaran IPA lebih bermakna bagi siswa sehingga keterampilan berpikir kritis IPA siswa dapat meningkat. Selain itu, model pembelajaran ini akan dapat menguatkan ingatan siswa terhadap materi yang dipelajarinya. Aktivitas belajar CTL (Contextual Teaching and Learning) dirancang dengan berbantuan masalah realistis.

Masalah realistis merupakan suatu pernyataan tentang keadaan yang belum sesuai dengan yang diharapkan di kehidupan nyata. Dengan berbantuan masalah realistis ini siswa belajar lebih rileks, karena pembelajaran ini mengkaitkan dengan kehidupan sehari-hari siswa. Disamping itu, dapat menumbuhkan tanggung jawab, kerjasama, persaingan sehat, dan keterlibatan belajar.

Keterampilan berpikir kritis adalah aktivitas mental sistematis yang dilakukan oleh orangorang yang toleren dengan pikiran terbuka untuk memperluas pemahaman mereka.

Berdasarkan beberapa permasalahan di semua SD yang terdapat di Gugus II Teuku Umar Denpasar Barat tersebut, keterampilan berpikir kritis IPA siswa kelas IV Gugus II Teuku Umar Denpasar Barat belum sesuai dengan apa yang diharapkan sehingga keterampilan berpikir kritis IPA siswa perlu ditingkatkan. Berdasarkan urain diatas, maka akan dilaksanakan penelitian yang bertujuan untuk mengetahui Pengaruh Model Pembelajaran Kontekstual Berbantuan Masalah Realistis Terhadap Keterampilan Berpikir Kritis IPA Siswa Kelas IV Gugus II Teuku Umar Denpasar Barat Tahun Pelajaran 2018/2019.

\section{Metode}

Penelitian ini dilakukan di kelas IV gugus II Teuku Umar Denpasar Barat yang terdiri atas 6 sekolah dasar negeri, diantaranya SDN 2 Dauh Puri, SDN 10 Dauh puri, SDN 12 Dauh Puri, SDN 13 Dauh Puri, SDN 14 Dauh Puri, SDN 21 Dauh Puri. Penelitian ini dilaksanakan 
pada semester II Tahun Ajaran 2017/2018. Waktu penelitian dilaksanakan mulai bulan Januari 2019 hingga bulan Mei 2019 yang diawali dengan penyusunan proposal hingga penyusunan skripsi selesai. Pelaksanaan penelitian ini dilakukan sebanayak 8 kali pertemuan yaitu 8 kali pertemuan di kelas eksperimen dan 8 kali pertemuan di kelas kontrol. Jenis Penelitian ini adalah kuasi eksperimen (quasy experiment). Pada penelitian ini desain atau rancangan penelitian yang digunakan adalah Non Equivalent Post-test Only Control Group Design. Desain penelitian ekperimen Non Equivalent Post-test Only Control Group Design dipilih karena subjek ekperimen tidak dirandomisasi untuk menentukan sampel dan ditempatkan dalam kelompok eksperimen dan kelompok kontrol. Desain ini menggunakan satu kelompok eksperimen dan kelompok kontrol. Kelompok eksperimen mendapatkan pelakuan, dan setelah itu diberi posttest. Sedangkan kelompok kontrol hanya diberikan post-test tanpa diberikan perlakuan.

Tabel 2. Desain Penelitian

\begin{tabular}{ccc}
\hline Kelompok & Perlakuan & Post-test \\
\hline$E$ & $\mathrm{X}$ & $\mathrm{O}_{1}$ \\
$\mathrm{~K}$ & - & $\mathrm{O}_{2}$ \\
\hline
\end{tabular}

Keterangan:

(Gribbons, 1997)

$\mathrm{E} \quad=$ Kelompok Eksperimen

$\mathrm{K} \quad=$ Kelompok Kontrol

$\mathrm{X} \quad=$ Perlakuan dengan Model Pembelajaran Contextual Teaching and Learning

$\mathrm{O}_{1} \quad=$ Post-test terhadap Kelompok Eksperimen

$\mathrm{O}_{2} \quad=$ Post-test terhadap Kelompok Kontrol

Populasi pada penelitian ini adalah seluruh siswa kelas IV SD Gugus II Teuku Umar Denpasar Barat Tahun Ajaran 2018/2019 yang berjumlah 240 siswa. Teknik pengambilan sampel yang digunakan dalam penelitian ini adalah teknik random sampling. Sampel yang dirandom dalam penelitian ini adalah kelas karena dalam eksperimen tidak memungkinkan untuk mengubah kelas yang ada. Kelas yang akan dirandom merupakan kelas dalam jenjang yang sama, kelas-kelas tersebut adalah kelas IV dari masing-masing sekolah dasar di Gugus II Teuku Umar Denpasar Barat.

Tahap pertama dilakukan pertama dilakukan uji kesetaraan menggunakan rumus ANAVA satu jalur dengan memberikan instrumen penilaian yang sama kepada seluruh populasi atau sekolah. Dari 6 SD yang ada di gugus II Teuku Umar Denpasar Barat diadakan undian untuk mengambil dua kelas yang menjadi sampel penelitian. Hasil undian diperoleh dua kelas yaitu kelas IV SD Negeri 13 Dauh Puri dan SD Negeri 14 Dauh Puri. Lalu kedua kelas tersebut diundi kembali untuk menentukan kelas eksperimen dan kelas kontrol. Berdasarkan hasil pengundian diperoleh sampel untuk kelompok eksperimen yaitu SD Negeri 13 Dauh Puri dengan jumlah 47 siswa dan kelompol kontrol SD Negeri 14 Dauh Puri dengan jumlah 40 siswa.

Data yang dikumpulkan dalam penelitian ini adalah data keterampilan berpikir kritis IPA. Pengumpulan data tersebut menggunakan metode tes. Tes dalam penelitian ini berbentuk tes tertulis dengan bentuk uraian yang memuat beberapa pertanyaan soal IPA. Jumlah butir tes yang dipergunakan untuk mengetahui keterampilan berpikir kritis siswa yaitu sebanyak 10 butir soal. . Tes tersebut telah di uji coba lapangan, sehingga teruji validitas, tingkat kesukaran, daya beda dan reliabilitasnya. Hasil tes uji lapangan tersebut selanjutnya diberikan kepada siswa kelas eksperimen dan kontrol sebagai post-test.

Analisis data yang digunakan dalam penelitian ini yaitu analisis statistik deskriptif dan data dianalisis dengan menghitung nilai mean, median, modus, standar deviasi, varian, skor maksimum, dan skor minimum. Dalam penelitian ini data disajikan dalam bentuk kurva poligon. Sedangkan teknik yang digunakan untuk menganalisis data guna menguji hipotesis penelitian adalah uji-t. Selanjutnya, untuk bisa melakukan uji hipotesis, ada beberapa persyaratan yang harus dipenuhi dan perlu dibuktikan. Persyaratan yang dimaksud yaitu: (1) data yang dianalisis harus berdistribusi normal, (2) kedua data yang dianalisis harus bersifat homogen. Untuk dapat membuktikan dan mememenuhi persyaratan tersebut, maka dilakukanlah uji prasyarat analisis dengan melakukan uji normalitas, dan uji homogenitas. 
TSCJ, Vol 1 No 2, Tahun 2018

\section{Hasil dan Pembahasan}

Pengukuran dilakukan setelah kelompok eksperimen diberikan perlakuan model pembelajaran CTL berbantuan masalah realistis dan kelompok kontrol tidak diberikan perlakuan model pembelajaran CTL berbantuan masalah realistis, sebanyak tujuh kali pertemuan dengan materi ajar yang sama. Analisis data dilakukan pada masing-masing kelas yaitu kelas eksperimen dan kelas kontrol. Adapun hasil analisis data statistik deskriptif disajikan pada Tabel 3.

Tabel 3. Analisis Data dengan Statistik Deskriptif

\begin{tabular}{ccc}
\hline Data & Eksperimen & Kontrol \\
\hline Rata-rata & 87,245 & 78,4 \\
Standar Deviasi & 7,4 & 5,747 \\
Varians & 54,763 & 33,023 \\
Nilai Maksimum & 97 & 93 \\
Nilai Minimum & 70 & 70 \\
\hline
\end{tabular}

Pada kelompok siswa yang dibelajarkan dengan model CTL berbantuan masalah realistis mendapat nilai rata-rata $(87,25)$.

Tabel 4. Kategori Keterampilan Berpikir Kritis IPA Kelompok Eksperimen

\begin{tabular}{cc}
\hline Rentang Skor & Klasifikasi/Predikat \\
\hline $75,05 \leq X \leq 100$ & Sangat Baik \\
$58,35 \leq X<75,05$ & Baik \\
$41,65 \leq X<58,35$ & Cukup \\
$24,95 \leq X<41,65$ & Tidak Baik \\
$0 \leq X<24,95$ & Sangat Tidak Baik \\
\hline
\end{tabular}

Mengetahui kualitas variabel keterampilan berpikir kritis IPA pada kelas eksperimen, skor rata-rata keterampilan berpikir kritis IPA siswa dikonversikan menggunakan kriteria rata-rata ideal $\left(\mathrm{M}_{\mathrm{i}}\right)$ dan standar deviasi ideal $\left(\mathrm{SD}_{\mathrm{i}}\right)$ maka diperoleh hasil konversi yang berada pada rentang $75,05 \leq X \leq 100$.

Jadi, rata-rata hitung data keterampilan berpikir kritis IPA kelompok siswa yang dibelajarkan dengan model CTL berbantuan masalah realistis dikategorikan sangat baik. Berdasarkan data pada Tabel 3, data hasil belajar kelompok eksperimen disajikan dalam bentuk kurva polygon, seperti Gambar 1.

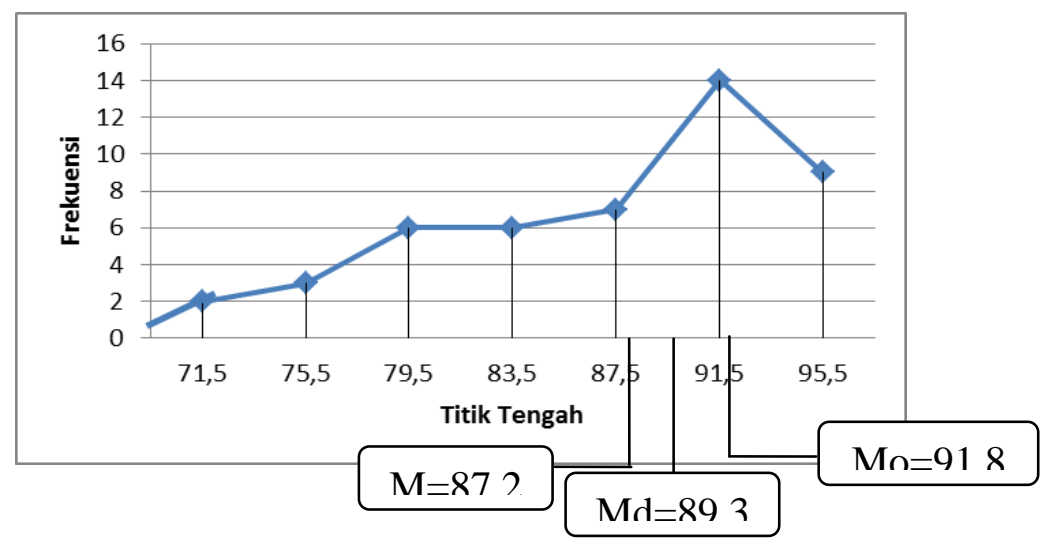

Gambar 1. Poligon data keterampilan berpikir kritis ipa siswa kelompok eksperimen

Berdasarkan kurva polygon data keterampilan berpikir kritis IPA kelompok siswa yang dibelajarkan dengan model CTL berbantuan masalah realistis, dapat diketahui bahwa modus 
lebih besar dari median dan median lebih besar dari mean (Mo $>M d>M)$. Dengan demikian, kurva diatas adalah kurva juling negative artinya, sebagian besar skor cenderung tinggi.

Sedangkan pada kelompok siswa yang tidak dibelajarkan dengan model CTL berbantuan masalah realistis mendapat nilai rata-rata $(78,40)$. Mengetahui kualitas variabel keterampilan berpikir kritis IPA pada kelas kontrol, skor rata-rata keterampilan berpikir kritis IPA siswa dikonversikan menggunakan kriteria rata-rata ideal $\left(\mathrm{M}_{\mathrm{i}}\right)$ dan standar deviasi ideal $\left(\mathrm{SD}_{\mathrm{i}}\right)$ sesuai tabel 4 maka diperoleh hasil konversi yang berada pada rentang $75,05 \leq X \leq 100$.

Jadi, rata-rata hitung data keterampilan berpikir kritis IPA kelompok siswa yang tidak dibelajarkan dengan model CTL berbantuan masalah realistis dikategorikan sangat baik. Berdasarkan data pada Tabel 3, data hasil belajar kelompok kontrol disajikan dalam bentuk kurva polygon, seperti Gambar 2.

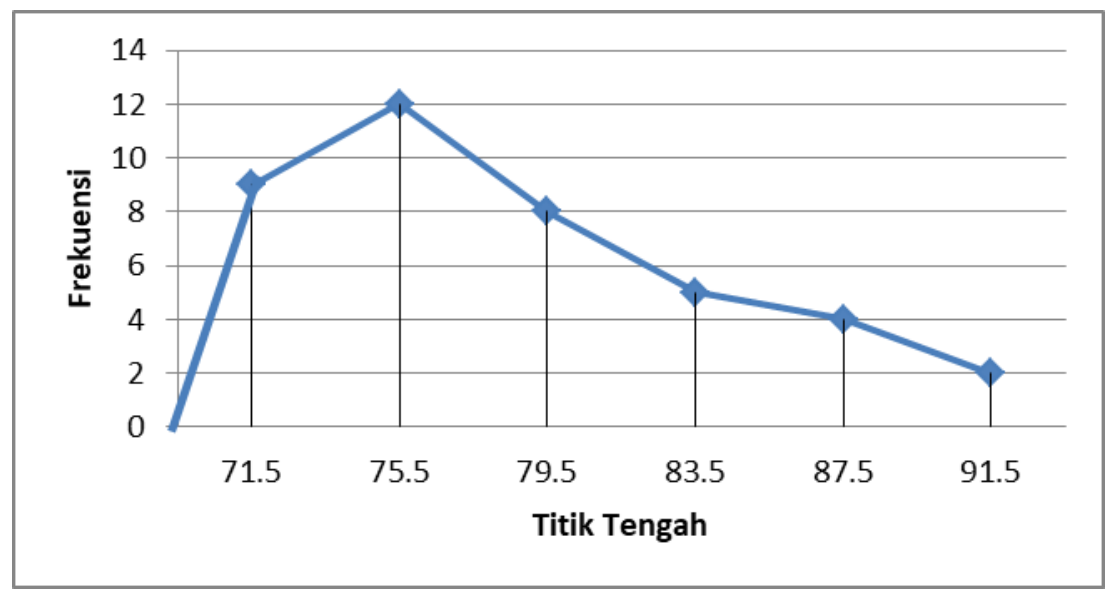

Gambar 2. Grafik poligon data keterampilan berpikir kritis ipa kelompok control

Berdasarkan kurva polygon data keterampilan berpikir kritis IPA kelompok siswa yang tidak dibelajarkan dengan model CTL berbantuan masalah realistis diatas, dapat diketahui bahwa modus lebih kecil dari median dan median lebih kecil dari mean (Mo<Md<M). Dengan demikian, kurva diatas adalah kurva juling positif. Artinya, sebagian besar skor cenderung rendah

Sebelum melakukan uji hipotesis maka harus dilakukan beberapa uji prasyarat. Terhadap sebaran data yang meliputi uji normalitas terhadap data skor keterampilan berpikir kritis IPA siswa. Uji normalitas ini dilakukan untuk membuktikan bahwa kedua sampel tersebut bedistribusi normal.

Adapun hasil perhitungan dari uji normalitas yaitu kelompok yang dibelajarkan menggunakan model pembelajaran CTL berbantuan masalah realistis (Kelompok Eksperimen) diperoleh $\left(\mathrm{X}^{2}\right.$ hitung $)$ adalah 8,383 dan $\left(\mathrm{X}^{2}\right.$ tabel $)$ dengan taraf signifikansi $5 \%$ dan dk $=5$ adalah 9,488 . Hal ini berarti, $\left(X^{2}\right.$ hitung $<X^{2}$ tabel) sehingga data hasil post-test kelompok eksperimen berdistribusi normal. Dan kelompok yang tidak dibelajarkan menggunakan model pembelajaran CTL berbantuan masalah realistis (Kelompok Kontrol) diperoleh $\left(x^{2}\right.$ hitung $)$ adalah 5,913 dan ( $X$ ${ }_{\text {tabel }}^{2}$ dengan taraf signifikansi $5 \%$ dan $d k=5$ adalah 9,488. Hal ini berarti, $\left(X^{2}\right.$ hitung $<X^{2}$ tabel $)$ sehingga data hasil post-test kelompok kontrol berdistribusi normal.

Tabel 5 .Hasil Uji Normalitas Sebaran Data Keterampilan Berpikir Kritis IPA

\begin{tabular}{|c|c|c|c|c|}
\hline No & $\begin{array}{c}\text { Kelompok Data } \\
\text { Keterampilan Berpikir } \\
\text { Kritis IPA }\end{array}$ & $x^{2}$ & $\begin{array}{l}\text { Nilai Kritis pada Taraf } \\
\text { Signifikansi } 5 \%\end{array}$ & Status \\
\hline 1 & Eksperimen & 8,383 & 9,488 & Normal \\
\hline 2 & Kontrol & 5,913 & 7,814 & Normal \\
\hline
\end{tabular}

Setelah melakukan uji prasyarat yang pertama yaitu uji normalitas, selanjutnya dilakukan uji prasyarat yang ke dua yaitu uji homogenitas varians. Hasil uji homogenitas varians data yang telah dianalisis adalah $F_{\text {hitung }}$ adalah 1,658 , sedangkan $F_{\text {tabel }}$ dengan db $_{\text {pembilang }}=46$, $\mathrm{db}_{\text {penyebut }}=40$, dan taraf signifikansi $5 \%$ adalah 1,679. Hal ini berarti nilai $F_{\text {hitung }}<F_{\text {tabel }}$ sehingga varians kedua kelompok homogen. 
TSCJ, Vol 1 No 2, Tahun 2018

p-ISSN : 2615-4692 e-ISSN : 2615-6105

Tabel 6. Hasil Uji Homogenitas Varians

\begin{tabular}{ccrrc}
\hline Sampel & Varians & $F_{\text {hitung }}$ & $F_{\text {tabel }}$ & Kesimpulan \\
\hline Kelas Eksperimen & 54,763 & 1,658 & 1,679 & Homogen \\
Kelas Kontrol & 33,023 & & & \\
\hline
\end{tabular}

Setalah uji normalitas dan homogenitas, selanjutnya dilakukan uji hipotesis atau uji-t, menggunakan uji-t sampel independent (tidak berkorelasi). Dengan hasil analisis perhitungan uji-t diperoleh $t_{\text {hitung }}$ sebesar 6,144 . Sedangkan $t_{\text {tabel }}$ dengan $d k=85$ dan taraf signifikansi $5 \%$ adalah 1,988. Hal ini berarti, $t_{\text {hitung }}$ lebih besar dari $t_{\text {tabel }}\left(t_{\text {hitung }}>t_{\text {tabel }}\right.$ ), sehingga Ho ditolak dan $\mathrm{H}_{\mathrm{a}}$ diterima. $\mathrm{H}_{\mathrm{a}}$ yang menyatakan bahwa terdapat perbedaan yang signifikan keterampilan berpikir kritis IPA siswa yang dibelajarkan melalui model pembelajaran Contextual Teaching and Learning berbantuan masalah realistis dan siswa yang dibelajarkan melalui pembelajaran langsung siswa kelas IV Gugus II Teuku Umar Denpasar Barat tahun pelajaran 2018/2019.

Tabel 7. Uji Hipotesis

\begin{tabular}{cccccccc}
\hline No & Sampel & Mean & Varians & $\mathrm{N}$ & $\mathrm{t}_{\text {hitung }}$ & $\mathrm{t}_{\text {tabel }}$ & Kesimpulan \\
\hline 1 & $\begin{array}{c}\text { Kelompok } \\
\text { Eksperimen }\end{array}$ & 87,245 & 54,763 & 47 & & & \\
& Kelompok Kontrol & 78,4 & 33,023 & 40 & & & \\
2 & & & & & \\
\hline
\end{tabular}

Hasil analisis data keterampilan berpikir kritis menunjukkan bahwa terdapat pengaruh pengaruh keterampilan pada pelajaran IPA yang dibelajarkan menggunakan model pembelajaran CTL berbantuan masalah realistis. Hasil analisi ini didasarkan pada rata-rata skor keterampilan berpikir kritis dan hasil uji-t. Pada kelompok siswa yang dibelajarkan model pembelajaran CTL berbantuan masalah realistis memperoleh skor keterampilan berpikir kritis IPA sebesar 87,245 yang termasuk kategori sangat baik, sedangkan pada kelompok siswa yang tidak dibelajarkan model pembelajaran CTL berbantuan masalah realistis memperoleh rata-rata sebesar 78,4 berada pada sangat baik. Pada hasil analisis uji-t diperoleh $t_{\text {hitung }}=6,144$ dan $t_{\text {tabel }}=1,988$ untuk dk 85 dengan taraf signifikansi $5 \%$. Merujuk pada hasil perhitungan uji-t dapat diketahui bahwa $t_{\text {hitung }}>t_{\text {tabel }}$, sehingga $H_{0}$ ditolah dan $H_{1}$ diterima. Perbedaan keterampilan berpikir kritis IPA antara kelompok eksperimen dan kelompok kontrol disebabkan langkah-langkah model pembelajaran CTL berbantuan masalah realistis melibatkan seluruh siswa untuk berpartisipasi aktif, seperti menemukan, bertanyadan membentuk pengetahuannya sendiri, sehingga tercapainya penguasaan materi pada mata pelajaran IPA.

Dalam melaksanakan pembelajaran IPA dengan menggunakan model pembelajaran CTL berbantuan masalah realistis siswa dapat lebih mudah membentuk pengetahuannya sendiri. Model pembelajaran CTL berbantuan masalah realistis merupakan suatu strategi pembelajaran yang menekankan pada proses keterlibatan siswa secara penuh untuk dapat menemukan materi yang dipelajari dan menghubungkannya dengan situasi kehidupan nyata sehingga mendorong siswa untuk dapat menerapkannya dalam kehidupan mereka. Model ini menuntut siswa menggunakan keterampilan berpikir, kemampuan mengembangkan pikirannya, serta skill siswa pada tingkat yang tinggi untuk keberhasilan serta berjalannya pembelajaran. Guru akan mengarahkan berjalannya pembelajaran, dan siswa melakukan arahan tugasnya. Pada akhirnya model ini menghasilkan siswa yang mandiri.

Pertama, model pembelajaran CTL berbantuan masalah realistis adalah kontruktivisme. kontruktivisme yaitu menemukan sendiri dan mengkonstruksi sendiri pengetahuan dan keterampilan barunya. Konstruktivisme adalah proses pembangunan atau penyusunan pengetahuan baru dalam struktur kognitif siswa berdasarkan pengalaman (Sanjaya, 2006). Hal ini menandakan bahwa dalam proses pembelajaran lebih mementingkan pada student centered daripada teacher centered, karena dalam proses pembelajaran sebagian besar proses belajar mengajar berbasis pada aktivitas siswa. Temuan ini sejalan dengan Asri (2012) yang mengungkapkan jika penguasaan konsep biologi siswa akan lebih efektif dibentuk melalui konstruksi peserta didik.

Kedua, model pembelajaran CTL berbantuan masalah realistis adalah inquiry. Pada tahap inquri, siswa aktif untuk mencari dan menemukan dalam memecahkan masalah. Nurhadi, dkk (2004) "pengetahuan dan keterampilan yang diperoleh oleh siswa diharapkan bukan hasil mengingat seperangkap fakta-fakta, tetapi hasil dari menemukan sendiri". Berdasarkan hal 
diatas, dalam proses pembelajaran guru harus selalu merancang kegiatan yang mengacu pada kegiatan menemukan, apapun materi yang diajarkan. Hal ini sejalan dengan temuan Damanhuri (2016) yang mengungkapkan siswa lebih semangat dalam mengerjakan soal-soal yang diberikan.

Ketiga adalah bertanya, pada tahap ini siswa mulai mengembangkan sifat ingin tahu siswa. Bertanya merupakan strategi utama yang berbasis kontekstual (Trianto, 2007). Bertanya merupakan suatu refleksi dari keingintahuan suatu individu. Dalam pembelajaran melalui pendekatan kontekstual guru tidak menyampaikan informasi secara langsung, akan tetapi dengan memancing agar siswa dapat menemukan sendiri. Oleh karena itu peran bertanya sangat penting, sebab bertanya merupakan suatu kegiatan yang dilakukan oleh guru untuk mendorong dan membimbing siswa untuk berpikir. Pernyataan ini sejalan dengan temuan Fayakun (2015) yang mengungkapkan pertanyaan dibentuk karena rasa ingin tahu siswa terhadap suatu fenomena yang baru. Siswa merasa asing dengan fenomena yang didemonstrasikan maka siswa perlu melakukan suatu percobaan untuk mendapatkan informasi yang diinginkan.

Keempat masyarakat belajar (learning community), pada tahap ini siswa belajar dalam kelompok. Konsep masyarakat belajar menyarankan agar hasil pembelajaran diperoleh melalui kerjasama dengan orang lain. Kerjasama ini dapat dilakukan melalui berbagai bentuk baik dalam kelompok besar secara formal maupun dalam lingkungan yang terjadi secara alamiah. Hal ini dilakukan dengan tujuan agar terjadinya suatu hubungan yang saling melengkapi dan saling membantu antara setiap individu dalam kelompok, dalam pembelajaran siswa dibagi menjadi kelompok-kelompok yang heterogen, sehingga siswa yang pandai dapat membantu siswa yang lemah, siswa yang tahu memberi tahu yang belum tahu, dan yang memiliki suatu gagasan bisa menyampaikan gagasan untuk menyelesaikan suatu masalah (Sanjaya, 2006). Temuan ini sejalan dengan hasil penelitian Sakah (2016) yang mengungkapkan jika penguasaan konsep matematika siswa akan lebih efektif dengan cara meningkatkan minat belajarnya.

Kelima modeling berbantuan masalah realistis, tahap ini guru menghadirkan model sebagai contoh pembelajaran yang berbantuan konteks nyata. Modeling dalam proses pembelajaran keterampilan atau pengetahuan tertentu bisa didapatkan siswa melalui pengamatan atau pembelajaran suatu model. Menurut Sanjaya (2006), "yang dimaksud pemodelan adalah proses pembelajaran dengan memperagakan sesuatu sebagai contoh yang dapat ditiru oleh setiap siswa". Dalam pembelajaran guru bukan satu-satunya model artinya pemodelan tidak terbatas dari guru saja, akan tetapi guru juga dapat memanfaatkan siswa yang dianggap memiliki kemampuan. Selain itu model juga didatangkan dari luar yang memiliki suatu keahlian sesuai dengan materi pembelajaran yang dibahas. Temuan ini sejalan dengan Fayakun (2015) menyatakan bahwa pemodelan bertujuan untuk memberikan konflik berpikir pada siswa. Siswa menganalisis dan mengevaluasi fenomena tersebut dengan pengetahuan yang dimilikinya.

Kelompok siswa yang dibelajarkan dengan menggunakan model pembelajaran CTL berbantuan masalah realistis menunjukkan hasil yang lebih baik yaitu sebagaian besar siswa sudah aktif dalam memecahkan suatu permasalahan yang diberikan oleh guru, aktif bertanya dan berani menanggapi pertanyaan teman maupun guru, dapat bekerja sama dengan baik dalam hal kelompok, dan percaya diri mempresentasikan hasil diskusi di depan kelas. Hasil penelitian ini diperkuat oleh Yulistya (2013) dengan judul "Pengaruh Pendekatan CTL Berbantuan Penilaian Kinerja Terhadap Pemahaman Konsep IPA Siswa Kelas V SD Negeri 1 Sangsit", demikian pula penelitian yang dilakukan oleh Hermawan (2013) dengan judul "Pengaruh Pendekatan CTL Berbasis Kearifan Lokal Terhadap Hasil Belajar IPA Siswa Kelas IV SD".

Pada kelompok kontrol diberikan pembelajaran dengan tidak menggunakan model pembelajaran CTL berbantuan masalah realistis. Kurang optimalnya keterampilan berpikir kritis yang diperoleh pada kelompok siswa yang tidak dibelajarkan dengan menggunakan model pembelajaran CTL berbantuan masalah realistis, dikarenakan siswa dibelajarkan dengan pembelajaran yang biasa dilakukan oleh guru yaitu proses pembelajaran lebih banyak terjadi satu arah dengan memberikan ceramah, tanya jawab dan evaluasi. Proses pembelajaran lebih berpusat pada guru dan menempatkan siswa sebagai pendengar dan pencatat. Siswa yang aktif selama pembelajaran adalah siswa yang mempunyai prestasi tinggi di kelas sedangkan siswa yang lainnya tidak terbiasa aktif berani bertanya dan menanggapi pernyataan teman lainnya. Metode-metode tersebut kurang tepat untuk pembelajaran yang bertujuan untuk menyelesaikan masalah-masalah yang ada dalam kehidupan sekitar siswa karena 
penyampaiannya yang mengutamakan komunikasi lisan membuat siswa terlihat bosan dalam menerima materi yang diajarkan dan siswa menjadi cenderung pasif.

Berdasarkan temuan-temuan pada kelompok siswa yang dibelajarkan dengan menggunakan model CTL berbantuan masalah realistis maupun kelompok siswa yang tidak dibelajarkan dengan menggunakan model pembelajaran CTL berbantuan masalah realistis, keterampilan berpikir kritis IPA yang dibelajarkan dengan menggunakan model pembelajaran CTL berbantuan masalah realistis lebih baik dibandingkan dengan siswa yang tidak dibelajarkan dengan menggunakan model pembelajaran CTL berbantuan masalah realistis. Hasil penelitian ini diperkuat oleh Yulistya (2013) dengan hasil penelitian menunjukkan perbedaan signifikan terhadap pemahaman konsep IPA siswa yang dibelajarkan menggunakan pendekatan CTL berbantuan penilaian kinerja dengan tidak menggunakan pendekatan CTL berbantuan penilaian kerja, demikian pula penelitian yang dilakukan oleh Hermawan (2013) dengan hasil penelitian menunjukkan perbedaan signifikan terhadap hasil belajar IPA yang dibelajarkan dengan pendekatan CTL berbasis kearifan lokal dengan dibelajarkan pendekatan konvensional.

Berdasarkan paparan di atas, maka dapat disimpulkan bahwa terdapat pengaruh model pembelajaran CTL berbantuan masalah realistis terhadap keterampilan berpikir kritis IPA siswa kelas IV SD di Gugus II Teuku Umar Denpasar Barat Tahun Pelajaran 2017/2018.

4. an dan Saran

Simpul

Berdasarkan rumusan masalah, tujuan penelitan, dan hasil penelitian dapat disimpulkan terdapat keterampilan berpikir kritis pada kelompok eksperimen dan kelompok kontrol, ini berarti bahwa terdapat pengaruh penggunaan model pembelajaran CTL berbantuan masalah realistis terhadap keterampilan berpikir kritis IPA siswa kelas IV SD di Gugus II Teuku Umar Denpasar Barat Tahun Pelajaran 2018/2019.

Berdasarkan simpulan yang telah dipaparkan, maka saran yang dapat diajukan adalah sebagai berikut. 1) Kepada Guru berdasarkan hasil penelitian, sebagai guru hendaknya agar lebih kreatif dalam mengembangkan inovasi pembelajaran dengan menerapkan strategi, pendekatan, model, dan metode yang mampu mengoptimalkan keterampilan berpikir kritis siswa. Salah satu desain pembelajaran yang mampu meningkatkan keterampilan berpikir kritis OPA siswa adalah dengan menerapkan model pembelajaran CTL berbantuan masalah realistis. 2) Kepada Kepala Sekolah berdasarkan temuan penelitian, kepada kepala sekolah sebaiknya agar dapat memperbaiki kualitas pembelajaran dengan memberikan sosialisasi secara berkelanjutan mengenai inovasi-inovasi pembelajaran untuk meningkatkan mutu muatan materi IPA pada khususnya dan semua muatan materi pada umumnya. 3) Kepada Peneliti Lain dilakukannya penelitian ini, disarankan agar hasil penelitian ini dapat dijadikan referensi atau sebagai informasi awal bagi peneliti lain untuk melakukan penelitian lebih lanjut dengan menggunakan model pembelajaran CTL berbantuan masalah realistis.

\section{Daftar Pustaka}

Agung, A. A. G 2016. Statistika Dasar untuk Pendidikan. Yogyakarta: Deepublish.

Alwasilah, Chaedar. 2007. Contextual Teaching and Learning. Bandung: MLC

Gunawan, Mumahmmad Ali. 2015. Statistik Penelitian Bidang Pendidikan, Psikologi dan Sosial. Yogyakarta: Parama Publishing.

Kesuma, Dharma. 2010. Contextual Teaching and Learning. Yogyakarta: Rahayasa Reasearch \& Training.

Rahayuni, Galuh. (2016). "Hubungan Keterampilan Berpikir Kritis dam Literasi Sains pada Pembelajaran IPA Terpadu dengan Model PBM dan STM" Jurnal Penelitian dan Pembelajaran IPA, Volume 2, Nomor 2 (halaman 131-146).

Ratna, Muttia. (2015). Pengaruh Metode CTL dan Kemampuan Berpikir Logis Terhadap Hasil Belajar IPA Siswa Kelas IV Sekolah Dasar Negeri 114 Palembang". Jurnal Pendidikan Dasar, Volume 6, Edisi 2 (halaman 254-265). 
Sadia, I Wayan. 2014. Model-Model Pembelajaran Sains Konstruktivisme. Yogyakarta: Graha IImu

Suastra, I Wayan. 2016. Pembelajaran Sains Terkini. Singaraja: Undiksha.

Suryani, Nunuk dan Leo Agung. 2012. Strategi Belajar Mengajar. Yogyakarta: Ombak.

Yulistya. 2013. "Pengaruh Pendekatan CTL Berbantuan Penilaian Konerja Terhadap Pemahaman Konsep IPA Siswa Kelas V SD Negeri 1 Sangsit". E-Journal Program Pascasarjana Universitas Pendidikan Ganesha Program Studi Pendidikan Dasar (Volume 4). Tersedia pada https://ejournal.undiksha.ac.id/index.php/JJPGSD/article/view/732/605 (diakses tanggal 31 Mei 2019).

Tirtasari, Ni Luh. (2015). "Penerapan Pendekatan Contextual Teaching and Learning Untuk Meningkatkan Hasil Belajar IPA Pada Siswa Kelas V". e-Journal Mimbar PGSD Universitas Pendidikan Ganesha. Volume 3, Nomor 1 (halaman 1-11).

Widowati, Asri (2012). "Optimalisasi Potensi Lokal Sekolah dalam Pembelajaran Biologi Berbasis Kontruktivisme" Journal UNY Vol : 2. Tersedia pada https://scholar.google.co.id/scholar?q=asri+2012+penguasaan+konsep+biologi\&hl=id\&as _sdt=0\&as_vis=1\&oi=scholart\#d=gs_qabs\&u=\%23p\%3Dv6_Zb7V8z2sJ 